\title{
Antropolojide Non-invaziv Görüntüleme Yöntemleri
}

\author{
Öznur GÜLHAN*®
}

' Dr. Arş. Gör., Ankara Üniversitesi, Antropoloji Bölümü, Ankara/TÜRKIYE

Öz

Son yıllarda görüntüleme teknolojilerinde meydana gelen yeni bilimsel keşifler ve yönlendirmeler, antropoloji araştırmalarında da oldukça önemli gelişmelerin meydana gelmesini sağlamıştır. Bu yeni bilimsel keșiflerin en önemlilerinden biri 19. yüzyıl sonları ve 20. yüzyllın başlarında keşfedilen radyolojik görüntüleme yöntemlerinin antropoloji araştırmalarında kullanılmaya başlanmasıdır. $\mathrm{Bu}$ yöntemler; bir nesnenin hem iç hem de dış özelliklerini, incelenen örneğin kendisini tahrip etmeden doğru sanal temsillerini oluşturarak incelenmesini sağlamaktadır. Bilgi teknolojilerindeki bu gelişmeler, antropolojik çalışmalar için yeni araştırma firsatları yaratmış ve Sanal antropoloji olarak adlandırılan yeni bir alan gelişmiştir. Böylece, dijital görüntüler antropolojik araştırmalarda her geçen gün daha fazla kullanım alanı bulmaktadır. Bu makale, hâlihazırda antropolojik araştırmalara dâhil edilen konvansiyonel radyografi, bilgisayarlı tomografi veya Mikro-BT ve ayrıca X-1şını içermeyen manyetik rezonans görüntüleme ve ultrason gibi çeşitli non-invaziv görüntüleme yöntemlerinin temel kullanımlarını gözden geçirerek bu yöntemlerin antropolojik çalışmalara nasıl fayda sağladığını ve gelecekteki potansiyellerini tartışmayı amaçlamaktadır.

Anahtar Sözcükler: Dijital görüntüleme teknikleri, Non-invaziv görüntüleme, Sanal Antropoloji, Üç boyutlu görüntüleme

\section{Giriş}

Son y1llarda, non-invaziv görüntüleme teknolojileri, özellikle radyolojik üç boyutlu görüntüleme yöntemlerinin kullanımı biyoloji, paleontoloji, biyolojik antropoloji, arkeoloji, adli bilimler ve malzeme bilimi dâhil olmak üzere birçok bilim alanına katkıda bulunmuştur (Uldin, 2017). Özellikle biyolojik antropoloji, fosil kalıntılarının incelenmesi ve iskelet kalıntılarının analizi için modern görüntüleme teknolojilerinden önemli ölçüde yararlanmış ve bu alanda yayınlanan çalışmaların sayısı son yıllarda hızla artmıştır. Dijital görüntüleme teknikleri antropologlara hem saha çalışmalarında hem de laboratuvar araştırmalarında pek çok avantaj sunmaktadır. Ancak bu teknikler henüz yeni kullanılmaya başlandığı için

\section{Non-invasive Imaging Methods in Anthropology}

Abstract

New scientific discoveries and directions have provided significant progress within the field of imaging technologies in recent years. One of the most important of these new scientific discoveries was the use of radiological imaging methods discovered in the late 19th and early 20th centuries in anthropological research. These methods enable the examination of both internal and external properties of an object by creating accurate virtual representations of the examined sample without destroying it. These developments in information technologies have created new research opportunities for anthropological studies and a new field called virtual anthropology has developed. Therefore, this article reviews the basic uses of various non-invasive imaging methods, such as conventional radiography, computed tomography, or micro-CT, as well as magnetic resonance imaging and ultrasound. The aim of this review is to discuss the benefit of using these imaging modalities for anthropological studies.

Key Words: Digital Imaging Techniques, Non-invasive imaging, Virtual Anthropology, Three-dimensional digitizing

gözden kaçabilecek bazı dezavantajlara da sahiptir. Bu makalenin amacı günümüzde birçok disiplinde kullanım alanı olan non-invaziv görüntüleme yöntemlerinin antropoloji disiplininde nassl değerlendirildiğini gözden geçirmek ve uygulama alanlarının gelişimi hakkındaki fikirleri değerlendirmektir.

\section{Antropolojide Non-invaziv Görüntüleme Yöntemleri}

Antropolojide kullanılan birçok non-invaziv görüntüleme yöntemi vardır ve bu tekniklerin birçoğunu radyolojik görüntüleme yöntemleri oluşturmaktadır. Bu yöntemler özellikle vücudun iç yapısı hakkında üç boyutlu (3B) veri elde etmek için sıklikla kullanılan tekniklerdir ve görüntüleme teknolojisindeki 
gelişmelerin antropoloji çalışmalarında yeni yaklaşımların tanıtılmasında önemli etkileri olmuştur. Bu bölümde, ileri görüntüleme yöntemlerinden olan ve antropolojide daha yaygın kullanım alanı bulan bilgisayarlı tomografi, Mikro-BT, konvansiyonel radyografi, ultrasonografi gibi iyonize olan radyasyon ve ultrasonografi ve manyetik rezonans gibi iyonize olmayan radyasyon kullanan bazı temel radyolojik görüntüleme yöntemleri sunulup tartışılmıştır.

\section{Konvansiyonel radyografi}

Konvansiyonel radyografi, adli tıpta en eski ve en sik kullanılan radyolojik görüntüleme yöntemlerinden biridir. $\mathrm{Bu}$ teknikte, vücut doğrudan $\mathrm{X}$ 1şınlarına maruz bırakılarak incelenir; ışına maruz kalan yapılar radyografik bir görüntüye yansittlır. Görüntü, dedektöre ulaşan X ışınlarının sayısına karşılık gelen farklı yoğunluklarda siyah ve beyaz tonlardan oluşur. Konvansiyonel radyografi, tıbbi kurumlarda bulunan iki tür cihazı kullanır. Görüntü izlenimi için radyolojik film kullanan analog donanım ve tamamen sayısallaştırılmış yeni donanım (Grabherr vd., 2016). Laboratuvar ve ev ofisi bağlamındaki bilgisayarların gelişimiyle birlikte radyografideki film basma devride sona ermiştir. Böylece 1980'lerde film basılarak kullanılan radyografilerden filmsiz (veya dijital) radyografilere geçiş sağlanmıştır. Film radyografisi genellikle dijital muadillerine göre daha pahalı, zaman alıcı ve kontrast açısından daha az manipüle edilebilirlerdir (Franklin vd., 2016). Dijital ve sayısallaştırılmış analog cihazlarda, görüntüler şu anda tüm görüntüleme yöntemleri için kullanılan dijital DICOM formatında elde edilir (Grabherr vd., 2016). Dijital radyolojinin avantajlarından biri de veri toplamanın kolaylığıdır. Günümüzde ise veri toplama yöntemi için kullanılan sistem Resim Arşivleme ve İletişim Sistemleri (PACS veritabanları) olarak adlandırılmaktadır ve bu sistem ile hem klinisyenler hem de araştırmacılar tarafindan kolayca erişilen ve paylaşılan bir veri yöntemi sistemidir (Franklin vd., 2016).

1895 yilında, Alman fizikçi Wilhelm Conrad Röntgen laboratuvarında "Röntgen'in 1şını" olarakta adlandırılan X-1şınlarını keşfetti (Grieshaber vd., 2008). $\mathrm{X}$-ş̧ınlarının keşfi, iç vücut yapılarının görselleştirilmesini kolay ve ağrısız bir şekilde yapılmasını sağladığı için tıp alanındaki uygulamalara yeni bir yol açtı. Bundan kısa bir süre sonra bu teknik antropoloji araştırmalarına uygulanmaya başlamıştır. Bu çalışmaların öncüllerinden bir tanesi 1898 yllında Petrie'nin Misır mumyalarını radyografik olarak incelediği araştırmasıdır (Grieshaber vd., 2008). Bir diğer araştırma ise yirminci yüzyllin başlarında paleoantropolog Gorjanoviç- Kramberger tarafindan X-1şınlarının Krapina Neandertallerinin iç kemik yapısının yaş tayini için kullandığı çalışmadır (Weber vd., 2001; Thali vd., 2011). Adli davalarda radyolojinin bildirilen ilk kullanımlarından biri ise Kanada'da 1895 yllında olmuştur. Bu vakada alt ekstremite kemiğine bitişik bir mermi pozisyonunun bir röntgeni kullanılmıştır, ancak bu yeni kanıt birçok mahkeme tarafindan reddedilmiştir (Thali vd., 2011). Adli antropoloji için radyografi uygulamasının ilk kabul edilen örneği 1927'de gerçekleşen Culbert'in davasıdır. $\mathrm{Bu}$ davada, antemortem ve postmortem radyografi kimliklendirme yapmak amacıyla karşılaştırılmıştır (Rock vd., 2006; Franklin vd., 2014). O zamandan beri, insan kalıntılarının kimliklendirilmesinde adli radyografi önemli bir rol oynamış ve çoğu adli kurum, travma durumlarında iskelet sistemini değerlendirmek veya yabancı bir cismin varlığını belirleyebilmek için kendi X-ray cihazlarına sahiptir. Günümüzde bilgisayarlı tomografi, konvansiyonel radyografi'ye tercih edilebilmektedir. Ancak, konvansiyonel radyografinin kolay ulaşılabilir olmasının yanısıra hızlı ve düşük maliyetli olması nedeniyle avantajlı tarafları vardır. Ayrıca, BT'nin oluşturduğu büyük hacimli görüntüler sebebiyle kullanılamadığı durumlarda incelenemeyen cesetlerin ve objelerin radyografi tarafindan görüntülenmesi gibi sebeplerle konvansiyonel radyografi antropolojide hâlâ önemli bir rol oynamaktadır (Grabherr vd., 2016).

\section{Ultrasonografi (US)}

Ultrasonografi (US), vücut içindeki yapiları görselleştirmek için yüksek frekanslı ses dalgalarını kullanan iyonize edici olmayan bir tıbbi görüntüleme tekniğidir. Potansiyel olarak radyasyon içermediğinden genellikle iyonlaştırıcı görüntüleme yöntemlerine alternatif olarak kullanilır (Franklin vd., 2016). Kemik yapısı, ultrason ile ses hızı (SOS) ve geniş bantlı ultrason atenüasyonu (BUS) parametleri kullanılarak ölçülür. Temel olarak kemikten geçip geri dönen ses dalgaları ile iletilir. Çoğu ekipman, ses dalgalarının atenüasyon seviyesini diğer algoritmalarla birlikte kullanarak görüntüyü yeniden oluştururlar. $\mathrm{Bu}$ parametreler genellikle kalkaneusta, el bilek kemiklerinde, tibiada ve patellada ölçülür (Darmawan vd., 2012).

Antropolojik çalışmalarda ultrason kullanımı iyonlaştırıcı teknolojiler kadar yaygın değildir (Franklin vd., 2016). Bununla birlikte, antropolojide ultrasonun kullanımıyla ilgili birçok araştırma bulmak mümkündür. Wagner ve ark. 1995 yllinda ultrasonun kemik yaş1 tayininde kullanılabilirliğini gösteren bir çalışma yayınlamışlardır. 2005 yılında ise Mentzel ve ekibi yeni bir sonografik yöntemin doğruluğunu standart radyografik yöntemle karşılaştırmışlardır. Kullandıkları bu sistem, cinsiyet ve etnik köken temelli algoritmalar kullanarak, distal radial ve ulna epifizinden geçen ses hizı ile büyüme arasındaki ilişkiyi değerlendirir. Bu yöntemin en büyük avantajı yukarıda da değinildiği üzere kullanılan teknolojinin iyonlaştırıcı radyasyon kullanmamasıdır. 
Buna rağmen, bu yöntem kullanıldığında bazı deneklere puan verilememesi, yaş sınırlarınının limitli olması ve yöntemin doğruluğunun radyografik değerlendirmeden daha az olması gibi dezavantajlara sahip olduğu bildirilmiştir (Darmawan vd., 2012).

Ultrasonografi hastanelerde kolayca erişilebilir olma, BT ve MRI'den daha az maliyetli olma avantajina sahiptir. Yapılan incelemeler hızlı ve gözlemciler içi ve aras1 uyum iyidir. Bununla birlikte ultrasonografi, uzun öğrenme eğrisi, deneyime bağlı analiz ve yorumlama gibi baz1 dezavantajlar sunar. Ayrica, baz1 anatomik bölgelerde, ultrason prob’u tüm epifiz yüzeyinin tamamını görüntüleyemez (Dedouit vd., 2015). Kıkırdak ve / veya kemik yapılarının görselleştirilmesinde, esasen sınırlı penetrasyon gücüne bağlı olarak ultrason ile ilgili bazı dezavantajların bulunduğunu, dolayısıyla daha derin yapılarda veya kaslı hastalarda görüntü kalitesinin düşmesine neden olduğunu belirtmek önemlidir (Franklin vd., 2016).

\section{Bilgisayarlı tomografi (BT)}

Antropologların çalışmalarında faydalandıkları görüntülüme tekniklerine son zamanlarda daha gelissmiş teknolojiler eklenmiş ve bu teknikler hızla antropolojik araştırmalara dâhil edilmeye başlanmış ve kullanımları gittikçe de artmıştır. Bu tekniklerden bir tanesi antropolojide kullanımı yaygın bir şekilde kabul gören ve çalışmalardaki doğruluk oranı oldukça yüksek olan Bilgisayarlı Tomografi (BT)'dir (Kahana ve Hiss, 1997).

Diğer görüntüleme yöntemleri gibi BT taramasıda antropolojik araştırmalarda büyük ölçüde kullanılmaktadır. BT ilk olarak 1963 yilında Allan Cormack tarafindan geliştirilmiştir (Robb, 1985; Grieshaber vd., 2008), ancak ilk ticari BT makinesi Sir Godfrey Newbold Hounsfield tarafindan 1972 y1lında resmi olarak tanıtılmıştır (Fleischmann ve Boas, 2011; Salzer, 2012). BT taraması gibi bir teknik, başlangıçta klinik ortamda kullanılmak üzere geliştirilmiş ve temel olarak tıbbi bir teşhis prosedürü olarak hâlâ kullanılmaktadır (Wu ve Schepartz, 2009). BT taramas1, farklı dokuların atenüasyon katsayılarına dayalı çoklu görüntüler üretmek için bilgisayarlı X-1şını makinesi kullanan bir görüntüleme tekniğidir. BT cihazları esasen tam açlardan bir dizi radyografi çeker ve elde edilen bu görüntüleri dijital algoritmalar ile birleştirilerek taranan nesnenin sanal bir 3B rekonstrüksiyonunu oluşturabilmek için istiflenebilen tomografik görüntüler üretirler. $\mathrm{Bu}$ prosedür, materyallerin ve organizmaların hem iç hem de dış yapılarının görselleştirilmesi için invazif olmayan tahribatsız bir metot oluşturur (Garvin ve Stock, 2016). BT taramaları, verileri enine kesit görüntülerine dönüştürmek için X 1şınları, algıllama sistemi ve bilgisayarı kullanır. Tarama yapılan her nesne veya kişi, farklı açılardan bir dizi X-ışınına maruz kalır
(Grieshaber vd., 2008). BT tarama teknikleri, yüksek kontrast çözünürlügünden dolayı yumuşak doku ve kemiklerin görüntülerini geleneksel X-sşını tekniklerine kıyasla daha ayrıntıllı, çarpıtmadan ve daha hızlı görüntü işleme süresince elde edilmesini sağlar. Bununla birlikte, kemik geometrisinin kaydedilmesinde yüksek düzeyde doğruluk sağlayabildikleri için, 3B kemik görüntü modellerinin yeniden yapılandırilmasinda altın standart hâline gelmiştir. Antropolojide BT kullanımı, geleneksel radyografi kullanımına göre birçok avantaja sahiptir; öncelikle hem kemiklerin hem de yumuşak dokuların daha ayrıntılı kontrast çözünürlükleriyle hazırlanan üç boyutlu bir görüntü oluşturmak mümkündür (Stull vd., 2014). Bu teknoloji, kalıntının tamamen bilgisayar ortamında yumuşak dokudan kemiği dijital ortamda parçalara ayrılarak incelenmesine olanak tanır (Grieshaber vd., 2008).

Antropoloji'de BT taramaları çeşitli şekillerde ve antropolojinin birçokaltdisiplinindekullanılabilmektedir. X-ş̧ını görüntülemede olduğu gibi, BT taraması geliştirildikten kısa bir süre sonra antropoloji disiplini bu teknolojiyi kullanılmaya başladı. Antropoloji'de kullanılan en erken BT kullanımının örneklerinden biri 1977 yllinda Lewin ve Harwood-Nash tarafindan taranan 14 yaşındaki bir çocuğun mumyalanmış beynidir (Thali vd., 2011; Grieshaber vd., 2008 ). Daha sonra ise 1984 yilında paleoantropolog Glen Conroy ve radyolog Vannier tarafindan, yoğunluk değişikliklerini ayırt etmek için yüksek çözünürlüklü BT taraması bir memeli fosiline ait kafatasına uygulanmıştır (Wu ve Schepartz, 2009). BT'nin adli antropoloji alanında sıklıkla kullanılmaya başlanması ise 1995 y1linda antemortem ve postmortem BT görüntülerinin karşılaştırılması ile birlikte bir kimliklendirme metodu olarak kullanılmasıly olmuştur. (Riepert vd., 1995; Rock vd., 2006). O zamandan itibaren BT adli antropoloji alanında pek çok uygulamada kullanılmaya devam etmektedir. Özellikle yumuşak dokusu bulunan kalıntılar üzerinde çalışlırken yumuşak dokuların kemiklerden ayrilma sürecini uygulamak yerine BT taraması ile inceleme yapılması araştırma süresinin kısalması ve kalıntiların belgelenmesini kolaylaştırmaktadır. Ayrıca, popülasyona özgü formüller oluşturmak için iskelet örnekleri bulunmadığında, antropologların uygun verileri elde etmek için farklı bir kaynak kullanması gerekebilir (Stull vd., 2014). Kalıntıların non-invaziv olarak görselleştirilme yeteneği, travmadan şüphelenilen durumlarda da önemlidir ve özellikle yerinde kırılmaları tanımada ve analiz etmede yardımcı olabilir. Kalıntılar sıklıkla iyileşen antemortem kırıkları, ateşli silah yaralanmaları ve perimortem kırı̆ğ paternlerinin tanınmasını kolaylaştırmak için adli antropolojik laboratuvarlarda radyografilere tabi tutulur. BT taraması bu incelemelerin aynısını gerçekleştirebilir, ancak BT taraması ile daha iyi bir çözünürlük ve 
BT’lerin sahip olduğu üç boyutluluk ve alan derinliği ile söz konusu nesnenin mekânsal ilişkilerinin daha iyi alg1lanması söz konusudur (Garvin ve Stock, 2016). $\mathrm{Bu}$ sebeple, günümüzde birçok çalışma hem felaket durumlarında (Rutty vd., 2007; Blau vd., 2008) hem de kriminal davalarda (Rouge vd., 1993; Riepert vd., 1995) kullanılmak üzere toplanan antropolojik bilgileri elde etmek için kemiklerin üzerindeki kalan etlerin siyrilması ve direk kemik üzerinden ölçüm alınmasına alternatif bir metot olarak BT'nin kullanılmasını önermektedir. Günümüzde BT aynı zamanda insansı kafataslarının sanal endokastlarını oluşturmak, fosilleşmiş bir kranium ile taş matriksi arasındaki sınırları belirleyerek endokranial kapasiteyi tahmin etmek ve iskelet materyalini toprak matriksinden ayırmak için de kullanılmaktadır (Chhem, 2006; Grieshaber vd., 2008).

Bununla birlikte BT verileri, sadece makroskopik kemik yüzeylerinin görselleştirilmesinden daha fazla bilginin değerlendirilmesine izin verir. Yüzeyin altında ne olduğuna bakmak, trabeküler kemik ve morfometrik analizler yapmak mümkündür (Villa vd., 2016). $\mathrm{Bu}$ uygulamalar, çoğunlukla paleoantropologlar ve bilgisayarlı görüntüleme uzmanları tarafından, birçok klinik radyoloğun ilgisinin ve teknik uzmanlığının ötesinde uygulamalar içermektedir (Chhem, 2006). Son zamanlarda, kemik ve eklem anatomisi ile kinematik çalışmaları için bir araç olarak üç boyutlu bilgisayarlı tomografi (3B-BT) ile ilgili birçok araştırma yapılmıştır. Bu çalışmaların yapılmasının en büyük nedeni, BT tarayıcılarının kemiklerden elde ettikleri 3B görüntülerinin yüksek çözünürlüklü olmaları sebebiyle çok parlak ve net olmalarıdır. 3B yeniden yapılandırılmıs görüntülerle ilgili literatürün çoğu medikal kullanımına odaklanmaktadır. Ancak, 3B rekonstrüksiyonlar üretmek ve bu 3B yeniden yapılandırılmış görüntülerden ölçümler almak için bilgisayar yazılımları kullanmak, adli antropoloji dâhil olmak üzere hem antropolojinin diğer alt disiplinlerine hem de diğer birçok bilim alanına faydalı olabilmektedir. Bu teknolojinin hem adli vakalarda hem de antropolojinin diğer araştırma alanlarında sağladığı önemli faydalara rağmen antropoloji araştırmalarının içerisinde kullanımı hâlâ oldukça sınırlı kalmaktadır. Bunun en büyük sebeplerinden biri BT tarayıcılarının kullanım maliyetinin yüksek olması ve bu sebeple birçok antropoloğun BT taraması yapmak için gerekli donanıma sahip tesislere erişimlerinin kısıtlı olması ya da hiç olmamasıdır. Ayrıca, BT görüntüleri ile çalışmak, özelleştirilmiş ve pahalı bilgisayar yazılımlarına erişimin yanı sıra 3B veri kümelerini yönetme deneyimini gerektirir. (Garvin ve Stock, 2016) Tüm bunların yanısıra BT görüntüleme tekniğinin en önemli sınırlamalarından biri, BT teknolojisinin farklı açılardan birçok bireysel radyografiyi yaratması nedeniyle hastaların X-1şını radyasyonuna yüksek dozda maruz kalmasıdır (Brenner,
2010). Bu nedenle, araştırmacilar ya tıbbi sebeplerle çekilen taramaların arşivlerini kullandıkları retrospektif çalışmalara (Decker vd., 2011; Franklin vd., 2012) ya da postmortem BT (Chiba vd., 2014) tekniklerini kullanabildikleri çalışmalara odaklanmışlardır.

\section{Manyetik rezonans görüntüleme (MRG)}

Manyetik rezonans görüntüleme (MRG), vücudun iç yapısının görüntülerini elde etmek için manyetik alanlar ve radyo dalgaları kullanarak vücuttaki suyun içinde bulunan hidrojen atomlarını tarar (Errickson vd., 2014). BT ve konvansiyonel radyografinin aksine, MRG iyonlaştırıcı radyasyon içermez (Franklin vd., 2016); nükleer manyetik rezonans prensibine dayanır. Bir hasta manyetik alana yerleştirildiğinde, radyo dalgaları vücuttaki hidrojen protonlarını uyarır. Hidrojen atomlarının çekirdeklerinden radyo frekansı yayılır ve protonlar1 $180^{\circ}$ lik bir pozisyona döndürür. Darbeden gelen enerji azaldikça, protonlar manyetik alan içindeki başlangıç durumuna geri döner ve dijital olarak görüntülere dönüştürülen bir MRG sinyali üretir. MRG; kasları, yağları, parankimayı ve nörolojik yapıları ayırt ettiği için mükemmel yumuşak doku kontrastının yanı sıra yüksek uzaysal çözünürlük sunar (Grabherr vd., 2016).

MRG'nin antropolojide sayısız kullanım alanı vardır ancak özellikle yaşayan bireylerde yaş değerlendirmesi için adli antropolojide oldukça önemli bir kullanım aracıdır (Dedouit vd., 2014). MRG kullanilarak görselleştirilen iskelet yaş çalışmalarına örnek olarak Dedouit ve ekibi (2012) tarafından yapılan çalışma gösterilebilir. $\mathrm{Bu}$ çalışmanın amacı, adolesan ve genç erişkinlerde iskelet yaşının yasal suçluluğunun belirlenmesinde MRG kullanılarak tahmin edilebileceği bir yaklaşım sağlamaktır. Yapılan çalışmada, bu tekniğin 25 yaş altı bireylerde yaş tahmini yapmak için pratik bir yol olduğu gösterilmiştir. Genel olarak MRG; künt kuvvet, bıçak yarası, tıbbi hatalar ve yaş tahmini durumlarında önerilmektedir. Yabanc1 cisimleri tespit etmek için de yararlı olabilir, ancak güçlü manyetik alanla etkileşime girebilecek ferromanyetik malzemelerle ilgili bazı k1sitlamalar vardır (Grabherr vd., 2016).

BT taraması gibi MRG de adli görüntülemede gittikçe daha yaygın hâle gelmektedir (Errickson vd., 2014). Hatta, MRG ile görüntü alırken iyonize olmayan radyasyon kullanmasından dolayı BT gibi diğer görüntüleme tekniklerine göre daha avantajlı sayılabilir (Dedouit vd., 2014; Grabherr vd., 2016). Ancak, PMCT-anjiyografiye benzer şekilde MRG'de ciddi bir şekilde değişmiş insan kalıntılarını tanımlamak için değerli veriler sağlamasına karşılık bu endikasyon için tercih edilen non-invaziv görüntüleme yöntemi genelde BT'dir (Grabherr vd., 2016). 


\section{Bilgisayarlı mikro tomografi (Mikro-BT)}

Bilgisayarlı Mikro Tomografi (Mikro-BT)'nin temel prensipleri, X-ışını emisyonuyla çalışan klinik bilgisayarlı tomografiyle aynıdır. Bununla birlikte, Mikro-BT çok daha fazla mekânsal çözünürlük sağlar ve bu nedenle görüntü kalitesi ve ayrıntısı limitlerin çokça ötesine geçmiştir (Rutty vd., 2013). Mikro-BT ilk kez 1980’lerin başında geliştirilmiş (Ritman, 2011) ve 1980'lerin sonunda ise Feldkamp ve ark. trabeküler kemiğin üç boyutlu mikro yapısının değerlendirilmesi için bir Mikro-BT tarayıcısı oluşturmuşlardır (Feldkamp vd., 1989). Mikro-BT’ler mikron düzeyde ölçüm yapabilen cihazlar oldukları için oldukça yüksek çözünürlüklü görüntü kalitesi sunmaktadır ve kullanımları gün geçtikçe artmaktadır (Mazurier vd., 2006; Wu ve Schepartz, 2009; Baier vd., 2017). Yaygin kullanımda

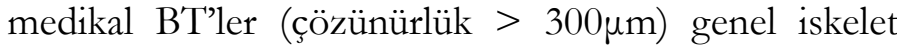
yaralanmalarının tespitinde ve izlenmesinde kullanışlı olmakla birlikte, tarama çözünürlüklerinin altında kalan önemli ve ayrıntılı anatomik detaylar gözlenmeyebilir.

Bununla birlikte, Mikro-BT özellikle adli antropolojide faydalı olabilecek mikro çatlaklar gibi özelliklerin dahi gösterilebilmesine olanak tanıyan çok daha yüksek çözünürlüklere $(0,5-120 \mu \mathrm{m})$ sahiptirler. Literatürde Mikro-BT; silah yaralanmaları, kesici alet yaralanmaları ve künt alet yaralanmaları da dâhil adli travma analizlerinde kullanılmaktadır. MikroBT, invazif olmadığ ve küçük özelliklerin gelişmiş görselleştirilmesine olanak sağladığı için kemikteki alet izlerinin incelenmesinde standart 1 şı k mikroskopisine göre birçok avantaj sunar (Baier vd., 2017).

Thali ve ekibi (2003), kemikte meydana gelen paternli yaralanmaların araştırılmasında Mikro-BT kullanımının faydalarını aktaran bir araştırma raporu yayınlamışlardır. Kendi tasarlamış oldukları MikroBT'yi kullanarak kemikte meydana gelen biçak yaralanmalarında Mikro-BT'nin potansiyel kullanımını araştırmışlardır. $\mathrm{Bu}$ çalışma ile kemiğe zarar veren bıçağın boyutunu ve şeklini nasıl belirleyebildiklerini göstermişlerdir. $\mathrm{Bu}$ nedenle, bu ilk makalede; MikroBT'nin "sınıf özellikleri” olarak adlandırılan yani genel boyutu, profili, şekli, bıçağın saplanma yönü ve yapmış olduğu hareketin kanıtlarını belgeleyebilmek için nasıl kullanılabileceğini göstermişlerdir. Bıçağın ucunun kırılmış parçası, şüpheli silahla tahribatsız ve grafiksel olarak ilişkilendirilebilir. Bireysel özellikler, örneğin cihazın yüzeyindeki kusurlardan ve düzensizliklerden kaynaklanan işaretler de Mikro-BT ile gözlenebilir. Bununla ilgili çalışmaya bir örnek olarak Pounder ve Sim'in tırtıklı bıçakla gerçekleştirilen bıçak yaralarının içindeki izleri araştırmak için Mikro-BT'nin nasıl kullanılabileceği ile ilgili 2011 yılında yapmış oldukları araştırma verilebilir (Rutty vd., 2013).
$\mathrm{Bu}$
ek olarak
Mikro-BT'nin

antropolojinin diğer alanlarında da kullanımı oldukça yaygındır. Literatürde Mikro-BT’nin; fosil çalışmalarında (Beck vd., 2012), paleopatoloji (Kuhn vd., 2007; Wade vd., 2011), diş (Le Cabec vd., 2015) ve histoloji çalışmalarına tamamlayıcı bir yöntem olarak (Baier vd., 2019) kullanıldığı gözlenmektedir. Tüm bu çalışmalar neticesinde Mikro-BT'nin bir nesnenin hem iç hem de dış özelliklerinin mikron altı çözünürlükte, örneği tahrip etmeden doğru sanal temsillerini oluşturma yeteneği ve bu görüntülerin kemiklerle direk yapılan çalışmalar ile karşılaştırılabilir sonuçlar üreten, hızlı, tekrarlanabilir bir yöntem olduğu için son dönemlerde antropolojide popüler bir yöntem hâline gelmiştir.

\section{DEXA-DXA kemik dansitometrisi}

Dual enerjili X-1şını absorpsiyometrisi (DEXA), kemik mineral yoğunluğunun ölçülmesinde kullanılan en yaygın tekniklerden biridir (Manifold, 2014). Absorptiyometri teknikleri, iskelet bölgesinde fotonik enerjinin emilimini ölçer. Dual enerji X-1şını absorpsiyometrisi (DEXA) iki enerji tepe noktası kullanır; bu özellik lomber omurga, kalça veya önkol gibi eşit olmayan yumuşak dokulara sahip kemik bölgelerini ölçmeyi mümkün kılar. DEXA ölçümü; hızı, doğruluğu ve hassasiyeti ile kemik kütlesini ölçmek için altın standart olarak kabul edilen bir yöntem hâline gelmiştir.

DEXA cihazı, ilgilenilen alanı hedef alan bir foton kaynağ1 olarak bir X-1şını tüpü kullanır. Bu foton kaynağ1 bir dedektöre mekanik olarak bağlanmıştır. Foton 1şınının içinden geçtiği dokudaki kemik mineralinin miktarı, detektöre ulaşan fotonların enerji miktarı ile hesaplanır; tespit edilmeyen fotonların kemik tarafindan emildiği kabul edilir (Castillo ve López Ruiz, 2011). Bu teknik özellikle son birkaç yıl içerisinde hızlı bir büyüme geçirmekte ve gün geçtikçe biyoarkeolojik materyallerin çalışılmasında DEXA kullanımı daha yaygın hâle gelmektedir. Bu alanda yapılan ilk çalışmalardan biri 1990 yllinda Hammerl ve arkadaşlarının arkeolojik bir kemik üzerinde osteoporozu araştırdıkları çalışmadır ve o günden beri popüler bir çalışma alanı hâline gelmiştir (Manifold, 2014).

DEXA taramalarından alınan radyasyon dozu oldukça düşük olduğu için kemik dansitometrisinin kullanımı birçok avantaja sahiptir ve antropolojide DEXA kullanımı için geniş bir alan vardır. Bunlar: vücut kitle indeksi hesaplamaları (Steinberger vd., 2005), iskelet uzunluğu hesaplamaları (Chinappen-Horsley vd., 2007), paleopatoloji (Mays, 2007), vücut yapis1 ve kompozisyon hesaplamaları (Albanese vd., 2003), yaş (Wheatley, 2005) ve adli antropolojide kullanımı çok yaygin olmasa da insan iskelet kalıntılarının tarihlenmesi ve tanımlanması için bir araştırma alanı açılır (Castillo ve López Ruiz, 2011). 


\section{Non-İnvaziv Görüntüleme Antropolojide Kullanım Alanları Fosil materyaller}

Sanal antropoloji yaklaşımı, modern insanın kökenleri ile ilgili birçok araştırmaya uygulanmıştır. Paleoantropologlar, fosilleşmiş hominin kraniyodental kalıntılarını sanal ortamda görüntüleştirerek, insan soyuna ve insan beyninin, kafatasının ve yaşam öyküsü modellerinin evrimine ilişkin bilgileri ortaya çıkardılar (Weber vd., 2001; Rein ve Harvati, 2014).

Fosilleşmiş iskelet materyallerinin araştırılmasında non-invaziv yöntemlerin kullanımı 19. yüzyılın sonlarından günümüze büyük bir bilimsel ilgi alanı olarak gelmektedir. W. Roentgen'in X-1şınlarını keşfetmesinden yalnızca biryıl sonra hem omurgalı hem de omurgasız fosil çalışmalarına radyografi uygulanmış ve daha sonrasında paleoantropoloji radyografiyi analitik bir araç olarak benimsemiş ve 1906 yllinda Krapina Neandertalleri ve 1908 y1lında Mauer mandibulas gibi hominin fosillerini incelemek için iki boyutlu radyografiler kullanılmıştır (Spoor vd., 2000). Ancak üçüncü boyuta yayilma, morfolojinin kalitatif ve kantitatif analiz olanaklarını çarpıcı biçimde arttırmıştır. BT teknolojisini kullanan ilk çalışmalardan biri Jungers and Minns'in 1979 yılındaki çalışmasıdır. Bu araştırma, fosilleşmiş hominid iskelet elemanlarının yapı, fonksiyon ve biyomekanik özelliklerini belirlemek için BT görüntülemenin kullanılmasının yararını göstermeyi amaçlamıştır. Soyu tükenmiş iki Prosimian'ın tibia ve femorası bir Homo sapiens'in morfolojisi ile karşılaştırılmıştır. Bu çalışma, iki örnek arasındaki yapısal farklılıkları aydınlatmak ve görsel teknolojinin matriks ve kemik arasındaki farkı nasıl ayırt edilebiceğini göstermek için 2 boyutlu taramaları kullanmıştır (Franklin vd., 2016). Bu çalışmayla birlikte iskelet ve fosil çalışmaları için yeni tanımlanmış olan BT yönteminin potansiyelinden faydalanan benzer çalışmalar hızla yapılmaya devam etmiştir (Weber vd., 2001; Daniel Franklin vd., 2016).

X-şsını teknolojisi, fosillerin ve kemiklerin içyapısının tahribatsız bir şekilde incelenmesine izin verirken, kullanılan yöntemde muhakkak dikkat edilmesi gerekilen noktalarda mevcuttur. Örneğin, fosilleşmiş kalıntılar X ışını görüntülemeye maruz kaldıklarında, içine gömüldükleri matriks özellikle de çevreleyen sediment, iskelet dokusundan daha yoğun veya benzer bir yoğunluğa sahipse görüntüyü bozabilir (Franklin vd., 2016). Bu sebeple, her çalışmaya uygun olan görüntüleme yöntemini seçmek önem kazanmaktadır. Son olarak, bu yöntemlerin yorumlama için büyük güç ve potansiyel sağlayabilecek araçları temsil ettiği daima akılda tutulmalıdır, ancak faydaları her zaman uygun araştırma tasarımına ve ele alınan araştırma sorularına bağlı olacaktır. Tüm bu zorluklara rağmen, sanal antropoloji alanındaki gelişmeler modern insanın kökenlerinin yanı sıra fosil kayıtlarının diğer yönleri hakkında da yeni bilgiler sunmaktadır. Bu yaklaşımlar doğada çok disiplinli bir yaklaşımla geliştirilmeye ve aynı zamanda yeni çalışma alanlarına da uygulanmaya devam etmektedir (Rein ve Harvati, 2014).

\section{Paleopatoloji}

Paleoradiyoloji; röntgen radyografisi, BT, MRG ve Mikro-BT gibi modern görüntüleme yöntemlerini kullanarak biyo-arkeolojik materyallerin incelenmesidir. Her ne kadar "paleoradyoloji" etimolojik olarak "eski radyoloji” anlamına gelse de paleopatoloji bağlamında kullanıldığında, terimin herhangi bir karışıklık olmadan, x-1şını testlerinin biyo-arkeolojik materyallere uygulanmasını tanımladığı açıktır. İnsan paleopatolojisi çalışmaları, uzun yıllardır radyolojik yöntemlerin kullanılmasından fayda sağlamıştır. Arkeolojik insan ve insan olmayan kalıntılardaki patolojilerin değerlendirilmesinde ve tanısında radyolojinin tanısal değeri daha belirgin hâle geldiğinden, tıbbi olmayan birçok merkezde konvansiyonel radyografiyi kullanan radyolojik tesisler kurulmuş ve elde edilen bu kalıntılar üzerinde yapılan bilimsel araştırmalar bu tesislerin merkezi durumuna gelmiştir. Paleopatolojik örnekler ile ilgili radyografik verilere daha fazla erişim sağlanmaya başlandığından beri biyolojik antropologlar bu görüntüleri yorumlama konusunda giderek daha yetkin hâle gelmektedirler (Chhem ve Brothwell, 2008).

Insan ve hayvan mumyalarının ilk röntgen çalışması, 1896 'da Koenig tarafindan yapılmıştır (Koenig, 1896) ve bundan sonra radyoloji çalışmaları hem paleopatoloji araştırmalarında hem de mumya çalışmalarında vazgeçilmez bir teknik olarak yerini almaktadır (Böni vd., 2004). Yukarıda bahsedildiği üzere radyografik görüntüleme cihazlarının kullanımının avantajları olduğu gibi dezavantajlara da sahiptir. Radyografik cihazlara ulaşımın pahalı olmasının yanısıra görüntü analizinde de bu alanda çalışan uzmanların dikkat etmesi gereken birçok nokta vardır. Örneğin, mezar ortamında, toprak bileşenlerinin genellikle arkeolojik insan iskelet kalıntıları ile iç içe geçmesi neticesinde tanımlamada ciddi engeller yaratması ve özellikle bu durumu tanımada deneyimsiz olanlar için gerçek zorluklar yaratabilmesidir. Toprak filtrasyonları kemikten daha yoğundur ve radyografik görüntülerde sklerotik alanlar olarak görülür. $\mathrm{Bu}$ bölgeler antemortem patoloji ile karıştırılabilir. Kemiğin ölüm sonrası parçalanması ayrıca mezar ortamında hem toprakta yaygin olarak karşılaşılan asidik koşullardan hem de bakteri, mantar ve böcek larvaları ve bitki kökleri dâhil organizmaların etkisinden meydana gelir. $\mathrm{Bu}$ yıkıcı süreçler osteolitik patolojik süreçleri taklit edebilir. Kemikteki tahrip edici kusurların sınırlarının ince detaylarına çok dikkat etmek, ölüm sonrası tahribat sorununu çözmek için gereklidir (Chhem ve Brothwell, 
2008). Bununla birlikte, kuru kemiklerin ve mumyaların basit görsel muayenesi, bu çalışmalarda antropologlar ve paleopatologlar tarafindan kullanılan en yaygin yöntem olmaya devam etmektedir. Daha yakın zamanlarda, patojenezi ve evrimsel iskelet patolojisini anlamamız ilerletmek için antik kemik ve dişleri değerlendirmek için mikro-BT çalışmaları yapılmıştır (Chhem, 2006).

\section{Arkeolojik örneklerde kemik mineral yoğunluğu (KMY)}

Kemik mineral yoğunluğu (KMY) klinik literatürde hem erişkinlerin hem de çocukların kemik sağlığ1 ile ilgili sıkça araştırma yapılan bir konudur. Çocukluk ve ergenlik dönemi boyunca iskelette oluşan büyüme ve gelişime bağlı değişiklikler kemiklerin hem boyutunda hem de yapisında meydana gelir ve bu değişiklikler aynı zamanda mineral içeriğinin artmasına neden olur. Çocukluk ve ergenlik döneminde kemik büyümesi ve mineralizasyon, yetişkin yaşamındaki kemik sağlığı için oldukça önemlidir. Yeterli beslenme ve fiziksel aktivite gibi faktörler büyüyen iskelete fayda sağlar ve kemik mineral yoğunluğu seviyesini yükseltir. KMY'deki bu artış, iskelet elemanlarının korunmakta olduğu bir rol oynayabilir.

Arkeolojik kalıntılardaki kemik yoğunluğu çalışmaları, DEXA ve QCT gibi tıbbi görüntüleme tekniklerinin kullanımıyla gelişmeye devam etmektedir, ancak bu teknikleri kullanmanın avantajları varken, iskelet materyali üzerinde kemik mineral yoğunluğunun çalışılmasında birçok kısıtlama da vardır. KMY; yaş, cinsel olgunlaşma, fiziksel aktivite miktarı ve kalsiyum gibi birçok faktörden etkilenebilir. Bu duruma örnek olarak toprak tarafindan meydana gelen kemiklerdeki kırılma ve hasarlar gibi oluşan postmortem değissiklikler verilebilir. Arkeolojik verilerle, modern verilerin birbirinin aynısı olması beklenemez ve bu sebeple mutlak KMY değerleri doğrudan yaşayanların değerleri ile karşılaştırılabilir değildir. Sağlık ve hastalıklardan dolayı, iskelet koleksiyonundan derlenen verilerde muhakkak bir kisitlama olacaktır ve bu sebeple direkt olarak karşılaştırılamazlar. Ancak iskelet kalıntıları ve modern klinik veriler arasında bazı geçerli karşılaştırmalar yapmak mümkündür. Bununla birlikte, iş pratiğe döküldüğünde DEXA ve QCT gibi özel ekipmanlara ulaşımın kısıtllilı̆ı, radyografik teknikerin tahsisi ve bu tarz bir görüntü almanın maliyeti gibi konular çalışmaları oldukça etkilemektedir (Manifold, 2014).

\section{Felaket kurbanlarını kimliklendirme (DVI)}

Felaket kurbanlarını kimliklendirme süreci, birden fazla bireyin aynı anda belli bir bölgede ölmesi ile gerçekleştiğinden adli antropologlar için farklı zorluklar içermektedir. Bu felaketler, uçak ve taşıt kazaları, patlamalar, depremler, yangınlar, bulaşıcı hastalık salgınları, toprak kaymaları, çamur kaymaları ve çığlar, kasırgalar, savaş ve kitle imha silahları olabilir. Bu nedenle, felaketlerde yer alan kişiler, insan vücudunun olağan yapısını bozabilecek çeşitli ve güçlü dış etkenlere maruz kalır (Blau vd., 2008). Bu güçlerin, kurbanların kalıntıları üzerinde dramatik etkileri olabilir ve bunun sonucunda kalıntılar yanmış, parçalanmış veya toplu hâlde birbirine karışmış şekilde bulunabilir (Ruder vd., 2012). Bu sebeple, non-invaziv görüntüleme yöntemleri, felaket kurbanlarının kimliklendirilmesi sürecinde önemli bir rol oynamaktadır.

Mevcut Uluslararası Suç Polis Teşkilatı'nın (Interpol) DVI kilavuz ilkelerinde kimliklendirme sürecinin ikinci aşamasında (ölüm sonrası soruşturma) radyolojik yöntemlerden kimliklendirme sürecinin bir parçası olarak bahseder. 26 Aralık 2004 tarihinde Hint Okyanusu Tsunami'sinden sonraki DVI sürecinde felaket kurbanlarının kimliklendirilmesinde kullanılan tek radyolojik metot diş röntgenidir. Felaket kurbanlarının kimliklendirilmesinde BT tekniğinin kullanıldığ ilk olay ise 2009 yılında Avustralya'nın Victoria kentinde yangının etkisiyle 173 kişinin öldüğü "Kara Cumartesi” orman yangınlarıdır. Orman yangını raporu, BT görüntülerinin yaş ve cinsiyet tahmininde veya $D V I$ için metalik tıbbi cihazların tespitinde faydalı bilgiler sağladığını vurgulamaktadır (Daniel Franklin vd., 2016; Iino ve Aoki, 2016).

DVI için önerilebilecek daha standart ve etkili bir seçenek olarak felaket sonucu toplanan tüm kalıntıların inceleme öncesinde toplu olarak radyolojik yöntemlerle taramasının yapılması gerektiği olabilir. Felaket bölgesinden toplanan tüm kalıntılara radyografik veya BT taramasının uygulanması birincil araştırma için tavsiye edilmekle birlikte ilk triyaj için yararlı bir protokol olarak önerilmektedir. Ancak günümüzde bu gibi kontekslerden çıkarılan kalıntılar için uygulanabilecek BT taramalarının toplanması, yönetimi ve değerlendirilmesi ile ilgili evrensel bir hüküm veya protokol yoktur. Böyle bir yaklaşımın uygulanması felaket kurbanlarının kimliklendirilmesi sürecine birçok avantaj getirecektir. Örneğin, toplu felaket bölgesinin güvenli bir şekilde temizlenebilmesi için bedenleri depolamadan önce her birinin kayıt altına alınmasının sağlanmasına olanak vermesidir. Yapilan taramalar daha sonra değerlendirilebilir veya hemen sanal otopsi için küresel olarak patologlara, antropologlara ve odontologlara elektronik olarak dağıtılabilir. Böylece sınırlı kaynaklarla mevcut alanda çalışan insan sayısı azaltılmış olmaktadır (Daniel Franklin vd., 2016).

\section{Antemortem klinik tanılar ve postmortem bulguların karşılaştırılması}

Adli antropologlar tarafindan kullanılan en yaygin kimliklendirme yöntemlerinden bir tanesi antemortem 
radyografik görüntülerin postmortem görüntülerle karşılaştırılmasıdır (Garvin ve Stock, 2016). İnsan kalıntılarının kimliklendirilmesinde radyolojinin kullanılmasinın en eski örneklerinden bir tanesi frontal sinüs farklılı̆̆ının bu kontekste potensiyelinin olduğunun farkedildiği 1921 yılıdır. Radyografik karşılaştırma yoluyla gerçekleştirilen ilk kimliklendirme ise 1927'de bir kafatas1 radyografisinin Hindistan'da bir nehirde keşfedilen ve çürüme dolayısıyla başka yollarla kimliklendirilmesi mümkün olmayan bir Amerika'lının tespitinde kullanıldığı zamandır (Culbert ve Law, 1927). Kimliklendirme sürecinde kullanılan karşılaştırmalı radyografi günümüzde oldukça sik kullanılan bir tekniktir. Ayrıca radyoloji, çeşitli tıbbi araştırmalar için ortak bir tanı aracı hâline gelmiştir, böylece karşılaştırma için antemortem kayıtların potansiyel kullanılabilirliğini arttırmaktadır (Christensen vd., 2014). Günümüzde ise antemortem ve postmortem radyografik karşlaştırma dünyadaki çoğu adli tesiste insan kalıntılarının kimliklendirilmesinde yaygin olarak kullanılan bir yöntemdir (Kahana ve Hiss, 1999).

Potansiyel bir eşleştirme bulunduğunda, kimliklendirme işlemi kimlik karşılaştırma aşamasına geçer ve bu aşamada kullanılabilecek karşılaştırma yöntemlerinden bir tanesi antemortem radyografi görüntülerinin postmortem radyofi görüntüleri ile karşılaştırılması sonucunda elde edilen bilgiler doğrultusunda yapılan kimliklendirme yöntemidir. Iskelet kalıntısının ait olduğuna inanılan birey hayatının herhangi bir döneminde klinik bir prosedürden dolay1 radyografik bir görüntüye sahipse bu görüntü bulunan iskelet kalıntılarından alınan radyografik görüntü ile karşılaştırılabilir ve bu iki görüntünün aynı kişiye ait olabileceğini gösteren iskelet özellikleri değerlendirilip kimliklendirmede kullanılabilir (Christensen vd., 2014). $\mathrm{Bu}$ nedenle karşılaştırma için gerekli bilgiler genellikle kolluk kuvvetleri veya tıbbi araştırma görevlileri tarafindan akraba veya tıbbi araştırma tesislerinden elde edilir. Daha sonra iki bilgi seti inecelenerek bu iki görüntünün aynı bireye ait olup olmadığı analiz edilir (Christensen vd., 2014).

Radyografik pozitif kimliklendirme genellikle antemortem ve postmortem görüntülerinüzerindeki bazı mevcut özelliklerin; örneğin, eski cerrahi veya ortopedik prosedürler gibi önceki tıbbi müdahale izlerini, protez cihazları, iyileşmiş travma kanıtlarını, frontal ve paranazal sinüslerin varyasyon ve konfigürasyonunu, konjenital malformasyonlar ve kalıntılarda belirgin olabilecek bazı büyüyen neoplazmalar gibi anatomik varyasyonların elde edilmesinde yardımcı olmaktadır (Kahana ve Hiss, 1999). Protezler, antemortem kırıkları ve konjenital veya travmatik deformasyonlar veya anormallikler gibi daha az yaygın özellikler muhtemel bir kimlinlendirme için çok daha faydalı olabilmektedir. İki radyografi görüntüsü tarafından ortak paylaşılan iskelet özelliklerinin sayısı arttıkça ve özellikler ne kadar olağandışı olursa bu özelliklerin aynı kişiyi gösterme olasıllğı o kadar yüksek olur (Christensen vd., 2014). Örneğin birçok araştırma, frontal sinüs morfolojisinin bireyler arasinda benzersiz olduğunu ve adli kimliklendirme için güvenilir bir şekilde kullanılabileceğini göstermiştir (Christensen vd., 2014; Garvin ve Stock, 2016). Frontal sinüs anatomisi bireye özgü yapıdadır ve daha önceki çalışmalar ikizlerde bile frontal sinüs radyografilerinin kişiye özgü olduğunu göstermiştir. Frontal sinüsün radyografik karşılaştırması kimliklendirme çalışmalarında sıkça başvurulan bir metotdur (Christensen vd., 2014). Diğer çalışmalar ise benzersiz kemik özelliklerinin, suture morfolojilerinin ve hatta trabeküler kemik yapılarının kimliklendirmeye yardımcı olabileceklerini göstermiştir. Bu araştırmalar özellikle antemortem bilgilerin potansiyel kurban havuzundan toplanabileceği kitlesel facialarda oldukça yararlı olabilen bir durumdur. Muhtemelen, vücudun herhangi bir bölgesindeki iskelet varyasyonları pozitif veya varsayımsal kimliklendirme için faydalı olabilir bu nedenle herhangi bir antemortem radyografinin bir kopyasının iskelet kalıntıları ile birlikte verilmesi herhangi bir esssiz morfolojinin değerlendirilebilmesi için önemlidir (Garvin ve Stock, 2016).

Tarihsel olarak bu kimliklendirme yaklaşımı antemortem ve postmortem düz film radyografilerinin karşılaştırılması ile başlamış ancak radyolojideki teknolojik gelişmeler, dijital radyografinin kullanımı, BT, MSCT ve MRG gibi diğer görüntüleme yöntemlerininde yaygın olarak kullanılmasına yol açmıştır (Christensen vd., 2014). Klinik ve cerrahi durumlarda bu yöntemler daha sık kullanılmaya başlandıkça kimliklendirme sürecinde bu yöntemlere de daha sık başvurulmaktadır. Mevcut durumda MSCT görüntülerinin karşılaştırılması düz radyografilerine göre daha az kullanılmasına rağmen radyoloji bölümlerinde rutin olarak yapılan BT incelemelerinin sayısında ki artış sebebiyle bu durum değissecek gibi gözükmektedir (Dedouit vd., 2014).

\section{Biyolojik profil oluşturma}

Bir kişinin gerçek kimliğinin belirlenebilmesi için öncelikle o kişiye ait en önemli özellilerden olan ölüm yaşı, cinsiyet, boy uzunluğu ve atasal yakınlı gibi faktörlerden oluşan biyolojik profilinin belirlenmesi gerekmektedir (Dedouit vd., 2010). BT ve daha yakın zamanda MRG ve US gibi görüntüleme teknikleri bu özelliklerin belirlenmesinde kullanılabilmektedir (Dedouit vd., 2014).

Atasal köken ve cinsiyet tahmini, özellikle de kalıntıların kötü bir şekilde korunduğu veya yandığ1 durumlarda oldukça zordur. Bununla birlikte, bir bireyin cinsiyetini belirlerken özellikle bazı kemiklerin incelenmesi önemlidir. Bunlar içerisinde, pelvisin şekli, 
büyüklüğü ve geometrisi, kafatası, mandibula ve uzun kemikler sıralanabilir. Ek olarak, trakeobronşiyal, tiroid ve aretenoid kıkırdaklar, iskelet kalıntılarından cinsiyeti radyolojik yönetemler kullanarak tahmin etmek için kullanılabilmektedir(Viner, 2018). Ayrıca, kostal k1kırdak kemikleşmesinin, radyolojik olarak incelendiğinde bir bireyin cinsiyetini tahmin etmede de yararlı olabileceği yapılan çalışmalar ile gösterilmiştir (McCormick, 1980; Middleham vd., 2015). Biyolojik antropologlar, iskelet kalıntılarından atasal kökeni belirlemek için kullandıkları yöntemleri radyografik metodları kullanarak yumuşak doku gözlenen kalıntılara da uygulayabilmektedirler. Özellikle, kranyum ve mandibulanin incelenmesi, femurun distal ucu ve uzun kemiklerin boyunun oran1 atasal kökenin belirlenmesinde yararlı olabilmektedir (Viner, 2018).

İskelet kalıntılardan ölüm yaşı tahmini hem adli antropoloji hem de biyoarkeolojide önemli bir konudur ve antropologlar kimliklendirilmemiş bir bireyin yaşını araştırmak için non-invaziv görüntüleme yöntemlerine başvurabilirler. Bu yöntem özellikle bebek ve çocuk bireyler için oldukça kullanışlıdır. Epifizyal kaynaşma ile birincil ve ikincil kemikleşme merkezlerinin varlığ1 veya yokluğu incelenerek fetal, bebek ve çocuk kalıntıların yaşlandırılması gerçekleştirilebilir (Garvin ve Stock, 2016; Viner, 2018). Makroskobik seviyede kısmen kaynaşmış epifizler tamamen kaynaşmış olarak görülebilir ancak radyografi ile incelendiğinde bu kısımda radyoopak kaynaşma hattı belirgin kalır. Jüvenil yaş tahmini için de kullanılan diş oluşumu ve diş sürme kalıplarını gözlemlemek veya sürmemiş herhangi bir dişi belirlemek için de en iyi değerlendirme yöntemi radyografidir. Yaş tahmini yöntemlerinin ağılıklı olarak büyüme ve gelişme yerine iskeletin aşınmasına bağlı olan yetişkin bireylerde radyolojik yöntemlerin kullanımı çok daha sinırlıdır. Bu gibi durumlarda, laringeal ve kostal kıkırdakların kemikleşmesinin radyolojik analizi bize geniş bir yaş aralığı verebilir. Ayrıca osteoporoz ve osteoartrit bulguları değerlendirilebilir (Garvin ve Stock, 2016).

Kısmen iskeletleşmiş kalıntılar söz konusu olduğunda ise bir BT kullanarak yapılan radyolojik inceleme, pübik simfisisten yaş tayini için özellikle yararlı olabilir (Dedouit vd., 2011; Viner, 2018). BT'nin antropolojik kullanımı temel olarak belirli BT kriterleri ve özelliklerine ya da fiziksel antropolojide ki kuru kemiklere uygulanan tekniklerin transpozisyonuna dayanır. Sonuç olarak, bu araştırmaları yapan kişiler, fiziksel antropoloji tekniklerine aşina olmalıdır. Yetişkinlerde, İşcan sınıflamasına göre sağ dördüncü kaburga görünümü, pübik simfisis, Suchey-Brooks sinıflamasina ve Lovejoy sinıflamasina göre auriküler yüzey en önemli ve en sık kullanılan yaş tayini metodlarıdır.

Bununla birlikte, BT ile tanımlanan auricular yüzeyin trabecular kemiğinin görünümü, sağ birinci kaburga ve klavikula yaş tayininde oldukça kullanışlı olabilmektedir. Bu alanda çalışan uzmanların bu yöntemlerin sınırlarının farkında olması, farklı ortalama yaş gruplarını bilmesi, kullanılan değişkenlerin standart sapmalarını ve gözlemciler arası ve gözlemciler içi uyum değerlerine hakim olması ve sonuçları belirli bir olasılıkla sunması gerekir (Dedouit vd., 2014). Yaş tayininde kullanılan bir diğer yöntem ise Mikro-BT'dir. Mikro-BT, pubis veya kaburga uçları gibi kemiklerin değerlendirilmesi ile yaşa bağlı değişikliklerin araştırılmasına yeni yollar açar. BT, kalıntıların sanal diseksiyonuna izin vermesine rağmen, mikro-BT; numunenin tamamen temizlenmesini gerektirmeyen ve uzaktan incelemeye izin veren makroskopik incelemeye eşdeğer yüksek çözünürlüklü görüntüleme sağlar. Bilgisayar yazılım araçlarını kullanarak, yüzey alanı değerlendirmelerinin yanı sıra kenarlar arasındaki mesafeler ve derinlikler gibi parametrelerin ölçülmesini sağlar. Bu, geleneksel yaş aralıklarının yaş tahmini için hassas bir şekilde ayarlanmasına olanak tanıyan, yaşa bağlı değişikliklerin yeni araştırma ve değerlendirme alanları için potansiyel yaratmaktadır (Rutty vd., 2013). Yetişkinlerde yaş tahmini için göz önünde bulundurulması gereken bir başka dijital teknoloji MRG'dir. BT ve MRG bilgilerinin birleşimi, özellikle yaşlı bireylerde çok geniş olan yaş tahmini aralıklarını daraltmaya yardımcı olabilir. Ancak şu anda bu teknoloji zaman alıcıdır ve kullanılabilirliği sınırlıdır; sadece birkaç araştırma kurumu bu teknolojiye sahiptir. Sonuç olarak modern referans koleksiyonları mevcut ve üzerinde çalışlan yöntemleri kalibre ederken nicel tarafsız yaş tahimini yöntemleri geliştirmek için kullanılmalıdır. Ayrıca, bu referans koleksiyonlarından elde edilen 3B modeller popülasyonlara özgü üç boyutlu kastların oluşturulması için de kullanılabilir (Villa vd., 2016).

Yetişkin olmayan bireylerde iskelet koleksiyonlarının azlığından dolayı mevcut standartların oluşturulmasının yetersizliği sebebiyle bu bireylerde boy tahmini nadiren yapilabilmektedir. Bu sorunun üstesinden gelmek ve bu bireyler için boy tahmini metodları oluşturabilmek amaciyla modern görüntüleme yöntemlerine başvurulmaktadır. Bu sebeple boy tahmininde anatomik yöntemin kullanımını değerlendirmek için MRG taramaları kullanılmaya başlanmıştır (Brits vd., 2018). Boy uzunluğu genellikle iskelet kalıntılarından doğrudan ölçümle tahmin edilebilmektedir. Femur kemiğinin uzunluğu boy tahmini çalışmalarında güvenilir olduğu gözlendiği için en sık kullanılan yöntemlerden biridir. Yumuşak dokunun kemik üzerinde gözlendiği durumlarda, düzeltme faktörü kullanıldığı müddetçe bu ölçümler aynı şekilde radyografik yöntemle yapilabilmektedir. Bununla birlikte BT tarama ve DR gibi modern görüntüleme teknikleri kullanılarak da 
boy uzunluğu tahmini gerçekleştirilebilmektedir. BT tarayıcılar ve dijital X-ray sistemleri otomatik olarak düzeltme hesaplamaları yapacak şekilde kalibre edilebilir, böylece ölçümler doğrudan görüntüden yapılabilir. BT taraması durumunda, daha önce tarif edilen manuel işlemin otomatik bir versiyonunu almak için tarayıcıy1 kullanarak bir skanogram gerçekleştirilir. Doğrudan ölçüm yapmak için bir yarık 1şını kullanan dijital X-1şını makineleri de kullanılabilir ve sonuçta elde edilen görüntülerden doğru anatomik ölçümler yapmak için diğer birçok doğrudan dijital X-1şını makinesi kalibre edilebilir (Viner, 2018).

\section{Travma}

Biyolojik profil oluşturmanın bir parçası olan travma ve patolojinin incelenmesi, bu lezyonlara sebebiyet veren olayların yeniden yapilandırılabilmesinin yanı sıra bireyin pozitif kimliklendirilmesine de yardımc1 olmaktadır (Daniel Franklin vd., 2016). Adli antropolojik araştırmalar sırasında travma ve patolojiyi tanımlamak için sanal teknolojiden faydalananarak yayımlanmış literatürde çok sayıda örnek vardır (Fleming-Farrell vd., 2013; Le Blanc-Louvry vd., 2013). Örneğin, şüpheli ateşli silah yaralanmaları durumunda, yalnızca olası mermi veya kurşun parçalarını aramak için değil, diğer kurşun transfer alanlarını belirlemek için de radyografiler çekilir. Dış etkenlere uzun süre maruz kalmış, tamamen iskeletleşmiş kafa iskeletinde bile kurşun, radyografik olarak giriş ve çıkış yaralarının çevresinde veya kurşundan etkilenen diğer endokraniyal yüzeylerde hâlâ gözlenebildiği belirtilmiştir. Dolayısıyla, kurşun transferinin belgelenmesi, antropoloğun mermi yolunu bulmasina yardımci olabilir.

Radyolojik yöntemler ayrıca kırık paternleri gibi diğer travma biçimlerini aramak ve belgelemek için de kullanılır. Adli antropologlar tarafindan alınan vakaların tümü tamamen iskeletleşmiş hâlde değildir ve böyle durumlarda non-invaziv görüntüleme yöntemlerinin uygulaması araştırma için hayati olabilmektedir. Kalıntılar tamamen iskeletmiş olsalar dahi bütün elementlerin radyografisi çekilmelidir. Radyografiler, trabeküler kemik paterninde kemik içi yeniden şekillenme veya bozulma belirtileri gösterebilir. Bu durum, antemortem travmanın bir göstergesi olabilir; bu da potansiyel olarak istismar bir davranış belirtilerinin tanımlanmasında veya tanınmasında yardımcı olabilir (Garvin ve Stock, 2016).

\section{Yaşayan bireylerde adli yaş tayini}

Bazı vakalarda adli antropologlar yaşayan bireylerden yaş tayini yapma durumunda kalmaktadır. Antropologlar iskeletleri konvansiyonel radyografi veya BT tarafindan sağlanan görüntüler aracilığ ile inceleyebilmektedir. Bunların yanısıra bazı durumlarda MRG de kullanılabilir. Genel olarak, yaşayan bireylerden alınan radyografik görüntüler kişinin yaşını gösteren herhangi bir resmî evrak olmadığı zaman ve yaşı hakkında belirsizlik söz konusu olduğunda veya resmi evrağı olmayan ve gerçek yaşını bilmeyen veya yaşı hakkında yalan söyleyen bireylerin kaç yaşında olduklarının tayini esnasında kullanılabilir. Bu değerlendirilmelerin yapılma sebebi hukuki ve ceza davaları olabileceği gibi sosyal nedenler (uygun okul eğitimi ve sosyal haklar) için de olabilir.

Ceza davaları için yaş tayininin en önemli sebebi kişinin ceza ehliyetine sahip olabilecek yaşta olup olmadığını belirlemek içindir. Yaşayan bireylerde yaş tayini değerlendirilmesi taleplerinin gerekli olabileceği bazı durumlar söz konusudur. Bu durumlar: resmi dökümantasyonu olmadan ülkeye girmiş olan mülteci ve sığınmacılar (örneğin bazı kültürlerde doğum günleri kutlanmayabilmektedir), belgesiz yaşadış1 göçmenler, insan kaçakçlloğ , küçük yaşta evlilik, çocuk ihmali vakaları, doğum kaydı olmayan ülkelerden evlat edinilen çocuklar, yaşı hakkında yalan söyleyen birinin yaşının tam olarak belli olmaması, çocuk suçlular, çocuk pornografisi ve rekabetçi çocuklar (örneğin olimpiyatlar) (Márquez-Grant, 2015). Özellikle Avrupa'da artan göç akımlarıyla birlikte yaşayan bireylerde uygulanan yaş tayini prosedürleri her geçen gün daha da artmaktadır. Özel yasalar çocukları koruduğu için, adli antropologlar ve adli tıpçılardan genellikle iltica talebinde bulunan ve 18 yaşında olduklarını ve ülkelerine geri iade edilmemeleri gerektiğini iddia eden kişiler için yaş tayini yapılması istenmektedir (Serin vd., 2016).

Adli sebeplerden dolayı yaş değerlendirilmesi yapilırken hekim radyasyona maruz kalma durumunu mümkün olduğunca azaltma ihtiyacını her zaman akılda tutmalıdır (Dedouit vd., 2015; Serin vd., 2016). Alman Adli Tıp Kurumu Adli Yaş Teşhisi Birimi (AGFAD) bazı vakalarda radyografi ve göğü BT taramasını önerir ve bu görüntüleme prosedürlerinin dolaylı veya doğrudan terapötik veya tanısal tıbbi yararı olmayan genç bireylere uygulandığı gözlenmiştir. Örneğin bir el radyografisi 0,1 mikrosievertten az radyasyon dozu, bir ortopantomogram 26 mikrosievert ve bir klavikula BT taramas1 600-800 mikrosievert civarında radyasyon yayar. Bu radyasyona maruz kalma durumu, birey riza gösterse dahi etik kaygıları artırmaktadır (Dedouit vd., 2015). Bu sebeple son zamanlarda MRG ve US gibi noninvaziv görüntüleme prosedürleri incelemede bulunulan bireyin radyasyona maruz kalmasinı en aza indirmek sebebiyle kullanılmaya başlanmıştır (Dedouit vd., 2015; Serin vd., 2016).

Son zamanlarda, manyetik rezonans görüntülemenin (MRG) yaş değerlendirmesine katkısı incelenmiştir, çünkü büyüme plakası olgunlaşmasını ve epifiz füzyonunu analiz etmek için etkili bir teknik gibi görünmektedir. MRG çalışmalarına bir örnek olarak Saint-Martin ve ekibinin (2013) 8-25 yaş aralı̆̆ındaki 
180 birey ile yapmış olduğu çalışma gösterilebilir. Bu çalışma sonucunda ayak ve ayak bileği MRG taramaları incelenerek distal epifiz ve kalkaneal epifiz için bir MRG evreleme sistemi geliştirmişlerdir. Her iki kemik için, metafiz ve epifiz arasındaki kaynaşma derecesi üç aşamada sınıflandırılmıştır. Yöntemin geçerliliğini ve tekrarlanabilirliğini gösteren gözlemci içi ve gözlemciler arası değişkenliğin sonuçları olumlu çıkmıştır.

\section{Tartışma}

Non-invaziv bir metot olan radyolojik görüntüleme yöntemlerinin insan vücudunu araştırmak için kullanılması uzun bir geçmişe sahiptir ve son y1llarda bu görüntüleme teknolojilerinin antropoloji çalışmalarının hemen hemen her sahasında kullanıldığına tanık olunmaktadır (Blau vd., 2008). Bilgi teknolojilerindeki gelişmeler, antropolojik çalışmalar için yeni araştırma firsatları yarattığından beri Sanal Antropoloji olarak adlandırılan yeni bir alan geliştirilmiştir (Kullmer, 2008).

Birçok laboratuvarda, müzede ve antropoloji araştırma merkezlerinde konvansiyonel radyografi, mikro-BT tarayıcıları, hatta BT ile yapılan antropolojik analizlerin kullanılmaya başlandığı gözlenmektedir (Villa vd., 2016). Non-İnvaziv görüntüleme yöntemlerinden biri olan radyoloji, fosil ve insan kalıntılarının ve bunlarla ilişkili parçaların analizi ve kimliklendirilmesi gibi geniş bir uygulama alanına sahiptir. Yukarıda bahsedildiği üzere radyolojik görüntüleme yöntemleri, antemortem ve postmortem görüntülerin karşılaştırılmasında (Haglund ve Sorg, 2010; Riepert vd., 1995), biyolojik profilin oluşturulmasında (Dedouit vd., 2007), kitlesel fekalet durumlarında (O’Donnell vd., 2011; Høyer vd., 2012), cinsiyet tahmini (McCormick, 1980; Middleham vd., 2015) ve yaş tayini (Dedouit vd., 2011) dâhil olmak üzere bir dizi spesifik postmortem analiz için kullanılmıştır. Ayrıca fosil (Spoor vd., 2000) ve paleopatolojik kalıntıların (Böni vd., 2004) incelenmesi için de uygulanmıştır.

Kullanilan bu non-invaziv görüntüleme teknolojilerinin hem avantajlar1 hem de dezavantajlar1 bulunmaktadır. Bu teknolojilerin sağladığı en önemi faydalardan bir tanesi taranan kemiklerin kalıc1 olarak belgelenmesine olanak tanımasıdır. Bu teknolojiler ile kullanılan gerçek örnek çeşitli nedenlerle analiz edilemese bile her zaman erişilebilen sanal kopyaları oluşturulabilmektedir. Ayrıca, sanal osteolojik koleksiyonlar dünyadaki araştırmacılar arasında verilerin daha kolay ve daha hızlı paylaşılmasını sağlayarak karşılaştırılmalı çalışmaları teşvik eder (Villa vd., 2016). Örneğin, non-invaziv görüntüleme iskeletin veya fosilin bulunduğu ülkede gerçekleştirilebilirken, görüntü analizi ve yeniden yapılandırma çalışmaları başka bir ülkede başka uzmanlar tarafindan devam ettirilebilir (Garvin ve Stock, 2016). Bu sanal kopyaların oluşturulmasının başka bir sebebi ise kemikleri daha fazla hasardan korumak ve aynı zamanda bu eşsiz ve kırılgan numuneleri eğitim materyali olarak kullanılabilir hâle getirmektir (Villa vd., 2016; Uldin, 2017). Bu durum özellikle çok fazla yanmış ve kömürleşmiş kemikler için ya da fosil kalıntılar için daha da geçerlidir. Böylece taranan cisim üzerinde nesneye zarar vermeden ondan tamamen bağımsız olarak başka çalışmalar yapılabilmektedir. Non-invaziv görüntülemenin bir diğer avantajı ise, örneğin sediment veya beton bloklara gömülü, fiziksel erişimin mümkün olmadığ1 kemiklere sanal olarak ulaşılmasını mümkün k1lmasıdır (Garvin ve Stock, 2016).

$\mathrm{Bu}$ teknolojilerin antropolojideki rutin kullanımı, gerekli maliyetler, uzmanlık ve verilerin toplanmasında ve işlenmesinde harcanan zaman nedeniyle sinurl kalmaktadır. Non-invaziv görüntüleme için kullanılan teknolojiler antropologların araştırma bütçelerinin oldukça üzerindedir. Bazı antropoloji laboratuvarları dijital röntgen sistemlerine bile erişemeyecek durumdadır. NextEngine tarayıc1 gibi uygun maliyetli görüntüleme seçenekleri bile, bazı analizleri gerçekleştirmek için ek yazilım gerektirebilir. Ücretsiz bazı yazılımlar mevcut olmakla birlikte, üç boyutlu verileri görüntülemek, toplamak ve analiz etmek için yaygın olarak kullanılan AMIR A, GeoMagic ve Polyworks gibi programlar, ylllk bakım ücretleriyle binlerce dolara mal olmaktadır.

Gelişmiş görüntüleme ekipmanının ve ilgili yazılımın kullanılması, aynı zamanda uzmanlık gerektiren ve bu teknolojilerden elde edilen verilerinin sonradan işlenmesini gerektirdiğinden sınırlayıcı bir faktördür (Garvin ve Stock, 2016). Bu sebeple, tüm antropoloji araştırma enstitülerinin non-invaziv görüntüleme yapabilen teknolojilere erişimi mümkün değildir. Ayrıca sağlık ve güvenlik risklerinin ortaya çıkabileceğinden, iskelet kalıntıları, özellikle de yüksek derecede bozulmuş ve ayrışmış cesetler için hastane görüntülüme ekipmanlarının kullanılması da doğru değildir (Blau vd., 2008).

Bununla birlikte, bu tür bir cihazın özellikle bir antropoloji araştırma enstitüsü içinde toplandığ1 veya bir mobil ünite olarak mevcut olduğu ortamlarda, non-invaziv görüntüleme yöntemlerinin mevcut $D V I$ işlemini tamamlamak veya kazı alanlarında mobil kullanım için muazzam bir potansiyeli vardır (Blau vd., 2008). Dijital görüntülemenin avantajlar1 ve günümüzün yüksek güçlü bilgisayarlarını kullanarak görüntüleri saklama, paylaşma ve analiz etme becerisiyle birleştiğinde, "daha basit" ve "daha uygun" maliyetli teknikler olan radyografi, floroskopi, skanografi ve tomografi gibi tekniklerin antropolojik materyallerin incelenmesindeki uygulamalarının daha da geliştirilmesi önem kazanmaktadır. Adli antropolojik ve paleoantropolojik incelemelerde BT ve MRG taramas1 gibi kesitsel radyolojik tekniklere erişim, teknoloji hem 
daha ekonomik hem de yaygın olarak kullanılabilir hâle geldiğinden, sürekli iyileştirilmektedir. Daha fazla doğruluk seviyesi ve örneklemleri inceleme ve görüntüleri üç boyutlu olarak görüntüleme yeteneği, antropologlara giderek daha geniş bir uygulama yelpazesi sunmaktadır (Viner, 2018).

Bu sinırlamalara rağmen, non-invaziv görüntüleme teknolojilerine erişimi olanlar, onları mevcut antropolojik analizler ve araştırmalara dâhil etmeye başlamıştır. 3B teknolojilerde ilerlemeler devam ettiği için veri toplama, işleme ve analiz prosedürlerinin otomatikleştirilmesine yönelik hareketler de dâhil olmak üzere, yeni ve daha nicel yöntemlerin sürekli gelişimini görmeyi beklemeliyiz. Fiziksel veri toplamak için koleksiyonlara seyahat etmenin yüksek para ve zaman maliyeti ve dijital verilere erişim kolaylığı göz önüne alındığında, sanallaştırmak için bu gelişmiş görüntüleme tekniklerini kullanan kurumların sayısı her geçen gün daha da artmaktadır. Bu sanal koleksiyonların oluşumu zaten zaman alıcıdır ve bu nedenle mütevazı koleksiyonların tamamen dijital hâle getirilmesi yıllar alabilir, ancak bu dezavantajlara rağmen, birkaç müze ve diğer kurumlar sanal koleksiyonlarına istikrarlı bir şekilde örnek eklemektedirler (Garvin ve Stock, 2016).

Gelişmiş görüntüleme tekniklerinin sürekli uygulanmasını ve geliştirilmesini teşvik etmenin asıl anahtarı, antropologların diğer disiplinlerle arasındaki iletişim ve veri alısverişinin sağlanarak yapıldığ1 çalışmalardan oluşan multidisipliner bir işbirliğini artırmaktır. Açı iletişim ve bilgi, veri ve kaynakların paylaşılması, disiplinlerarası işbirliğini kolaylaştıracak ve sonuçta bilimsel araştırmalardaki ortak hedeflerimizi destekleyecektir. Radyologlar ve biyolojik antropologlar arasındaki iş birliği radyolojik yöntemlerin antropolojik araştırmalarda artmasıyla birlikte her geçen gün daha da önem kazanmaktadır. Yukarıda belirtildiği gibi, arkeolojik kalıntıların radyolojik analizleri oldukça detaylı olabilmekte ve bu hassasiyetle yaklaşılmadığ1 zaman problemler olabilmektedir. $\mathrm{Bu}$ sebeple, bu verilerin doğru yorumlanabilmesi için bunların tespit edilmesi ve çözülmesi gerekmektedir.

\section{Sonuç}

Son on yllda, adli araştırma ve vaka analizlerinde gelişmiş görüntüleme tekniklerinin kullanımı katlanarak artmıştır. Non-invaziv görüntüleme yöntemlerinden elde edilen veriler ile osteolojik veriler arasındaki farkların adli sonuçları etkileyecek kadar büyük olup olmadığını değerlendirmek için daha ileri validasyon çalışmaları gereklidir. Ayrıca, bu teknolojiler kullanılarak oluşturulan 3B modeller, modern insanlarda, atalarında ve en yakın akrabalarındaki kemiklerin 3 boyutlu morfolojik varyasyonlarının objektif olarak değerlendirilmesine olanak sağlayan morfometrik analizler içinde kullanılmaktadır. Şu anda, osteolojik ölçümler genellikle altın standart olarak kabul edilir ve antropologların sunduğu çalışmaların bir çoğu sanal verilerin mevcut olduğu ve osteometrik verilerin bulunmadığ 1 birkaç araştırmadan ibarettir. Büyük miktarda örneklerin sanal 3B modelleri toplandığından sanal iskelet koleksiyonlarının geliştirilmesinin yanında sanal-spesifik veri toplama yöntemlerinin, analizlerinin ve ölçüm veri tabanlarının oluşturulmaya başlandığını görebilmekteyiz.

Sonuç olarak, radyologlar, radyografi teknikerleri, yazilım mühendisleri, patologlar ve antropologlar arasındaki iletişim ve veri alışverişi sağlanarak yapılan çalışmalardan oluşan multısidipliner bir yaklaşım, yukarıda bahsedilen kaynak kısıtlamalarının bir kısmını hafifletmeye yardımc olabilir ve antropolojik analiz ve araştırmalardaki ilerlemeleri kolaylaştırabilir.

\section{Kaynakça}

Albanese, C. V, Diessel, E., ve Genant, H. K. (2003). Clinical applications of body composition measurements using DXA. Journal of Clinical Densitometry, 6(2), 75-85. DOI: 10.1385/ JCD:6:2:75

Baier, W., Mangham, C., Warnett, J. M., Payne, M., Painter, M., ve Williams, M. A. (2019). Using histology to evaluate micro-CT findings of trauma in three post-mortem samples — First steps towards method validation. Forensic Science International, 297, 27-34. DOI: 10.1016/j.forsciint.2019.01.027

Baier, W., Norman, D. G., Warnett, J. M., Payne, M., Harrison, N. P., Hunt, N. C. A., ve Williams, M. A. (2017). Novel application of three-dimensional technologies in a case of dismemberment. Forensic Science International, 270, 139-145. DOI: 10.1016/j. forsciint.2016.11.040

Beck, L., Cuif, J. P., Pichon, L., Vaubaillon, S., Dambricourt Malassé, A., ve Abel, R. L. (2012). Checking collagen preservation in archaeological bone by non-destructive studies (Micro-CT and IBA). Nuclear Instruments and Methods in Physics Research Section B: Beam Interactions with Materials and Atoms, 273, 203 207. DOI: $10.1016 /$ i.nimb.2011.07.076

Blau, S., Robertson, S., ve Johnstone, M. (2008). Disaster victim identification: new applications for postmortem computed tomography. Journal of Forensic Sciences, 53(4), 956-961. DOI: 10.1111/j.1556-4029.2008.00742.x

Böni, T., Rühli, F. J., ve Chhem, R. K. (2004). History of paleoradiology: early published literature, 1896-1921. Canadian Association of Radiologists Journal, 55(4), 203-210.

Brenner, D. J. (2010). Should we be concerned about the rapid increase in CT usage? Reviews on Environmental Health, 25(1), 63-68. DOI: $10.1515 /$ REVEH.2010.25.1.63

Brits, D., Manger, P. R., ve Bidmos, M. A. (2018). Assessing the use of the anatomical method for the estimation of sub-adult stature in Black South Africans. Forensic Science International, 283, 221.e1-221.e9. DOI: 10.1016/j.forsciint.2017.11.024 
Castillo, R. F., ve López Ruiz, M. del C. (2011). Assessment of age and sex by means of DXA bone densitometry: Application in forensic anthropology. Forensic Science International, 209(1-3), 53-58. DOI: $10.1016 /$ i.forsciint.2010.12.008

Chhem, R. K. (2006). Paleoradiology: imaging disease in mummies and ancient skeletons. Skeletal Radiology, 35(11), 803-804. DOI: $10.1007 / \mathrm{s} 00256-006-0144-\mathrm{y}$

Chhem, R. K, ve Brothwell, D. (2008). PaleoRadiology: Imaging Mummies and Fossils. Berlin, Heidelberg: Springer-Verlag Berlin Heidelberg. DOI: $\underline{10.1007 / 978-3-540-48833-0}$

Chiba, F., Makino, Y., Motomura, A., Inokuchi, G., Torimitsu, S., Ishii, N., ... ve Iwase, H. (2014). Age estimation by quantitative features of pubic symphysis using multidetector computed tomography. International Journal of Legal Medicine, 128(4), 667673. DOI: $10.1007 / \mathrm{s} 00414-014-1010-4$

Chinappen-Horsley, U., Blake, G. M., Fogelman, I., ve Spector, T. D. (2007). A method for determining skeletal lengths from DXA images. BMC Musculoskeletal Disorders, 8, 113. DOI: 10.1186/1471-2474-8-113

Christensen, A. M., Passalacqua, N. V., ve Bartelink, E. J. (2014). Forensic Anthropology: Current Methods and Practice. Amsterdam: Elsevier Academic Press. DOI: 10.1016/C2013-0-09760-5

Culbert, W. L., ve Law, F. M. (1927). IDENTIFICATION BY COMPARISON OF ROENTGENOGRAMS OF NASAL ACCESSORY SINUSES AND MASTOID PROCESSES. Journal of the American Medical Association, 88(21), 16341636. DOI: $10.1001 /$ jama.1927.02680470020009

Darmawan, M. F., Yusuf, S. M., Haron, H., ve Kadir, M. R. A. (2012). Review on Techniques in Determination of Age and Gender of Bone Using Forensic Anthropology. In Proceedings of 2012 Fourth International Conference on Computational Intelligence, Modelling and Simulation (pp. 105-110). DOI: 10.1109/CIMSim.2012.58

Decker, S. J., Davy-Jow, S. L., Ford, J. M., ve Hilbelink, D. R. (2011). Virtual Determination of Sex: Metric and Nonmetric Traits of the Adult Pelvis from 3D Computed Tomography Models. Journal of Forensic Sciences, 56(5), 1107-1114. DOI: 10.1111/j.1556-4029.2011.01803.x

Dedouit, F., Auriol, J., Rousseau, H., Rougé, D., Crubézy, E., ve Telmon, N. (2012). Age assessment by magnetic resonance imaging of the knee: A preliminary study. Forensic Science International, 217(1-3), 232.e1-232.e7. DOI: 10.1016/j. forsciint.2011.11.013

Dedouit, F., Saint-Martin, P., Mokrane, F.-Z., Savall, F., Rousseau, H., Crubézy, E., ... Telmon, N. (2015). Virtual anthropology: useful radiological tools for age assessment in clinical forensic medicine and thanatology. La Radiologia Medica, 120(9), 874 886. DOI: $10.1007 / \mathrm{s} 11547-015-0525-1$

Dedouit, F., Savall, F., Mokrane, F.-Z., Rousseau, H., Crubézy, E., Rougé, D., ve Telmon, N. (2014). Virtual anthropology and forensic identification using multidetector CT. The British Journal of Radiology, 87(1036), 20130468. DOI: 10.1259/ bjr.20130468

Dedouit, F., Telmon, N., Costagliola, R., Otal, P., Joffre, F., ve Rougé,
D. (2007). Virtual anthropology and forensic identification: report of one case. Forensic Science International, 173(2), 182187. DOI: $10.1016 /$ j.forsciint. 2007.01 .002

Dedouit, F., Telmon, N., Hervé, R., Francis, E., Joffre, C., ve and Daniel, R. (2010). Modern Cross-Sectional Imaging in Anthropology. In M. J. Thali, M. D. Viner, \& B. G. Brogdon, Brogdon's Forensic Radiology (Second Edition) (pp. 107-126). Boca Raton: CRC Press.

Errickson, D., Thompson, T. J. U., ve Rankin, B. W. J. (2014). The application of $3 \mathrm{D}$ visualization of osteological trauma for the courtroom: A critical review. Journal of Forensic Radiology and Imaging, 2(3), 132-137. DOI: 10.1016/j.jofri.2014.04.002

Feldkamp, L. A., Goldstein, S. A., Parfitt, M. A., Jesion, G., ve Kleerekoper, M. (1989). The direct examination of three-dimensional bone architecture in vitro by computed tomography. Journal of Bone and Mineral Research, 4(1), 3-11. DOI: $10.1002 / \mathrm{jbmr} .5650040103$

Fleischmann, D., ve Boas, F. E. (2011). Computed tomographyold ideas and new technology. European Radiology, 21(3), 510 517. DOI: $10.1007 / \mathrm{s} 00330-011-2056-z$

Fleming-Farrell, D., Michailidis, K., Karantanas, A., Roberts, N., ve Kranioti, E. F. (2013). Virtual assessment of perimortem and postmortem blunt force cranial trauma. Forensic Science International, 229(1-3), 162.e1-162.e6. DOI: 10.1016/i. forsciint.2013.03.032

Franklin, D., Cardini, A., Flavel, A., ve Marks, M. K. (2014). Morphometric analysis of pelvic sexual dimorphism in a contemporary Western Australian population. International Journal of Legal Medicine, 128(5), 861-872. DOI: $\underline{10.1007 /}$ s00414-014-0999-8

Franklin, D., Flavel, A., Kuliukas, A., Cardini, A., Marks, M. K., Oxnard, C., ve O'Higgins, P. (2012). Estimation of sex from sternal measurements in a Western Australian population. Forensic Science International, 217(1), 230.e1-230.e5. DOI: 10.1016/j.forsciint.2011.11.008

Franklin, D., Swift, L., ve Flavel, A. (2016). 'Virtual anthropology' and radiographic imaging in the Forensic Medical Sciences. Egyptian Journal of Forensic Sciences, 6(2), 31-43. DOI: 10.1016/j. ejfs.2016.05.011

Garvin, H. M., ve Stock, M. K. (2016). The Utility of Advanced Imaging in Forensic Anthropology. Academic Forensic Pathology, 6(3), 499-516. DOI: $10.23907 / 2016.050$

Grabherr, S., Baumann, P., Minoiu, C., Fahrni, S., ve Mangin, P. (2016). Post-mortem imaging in forensic investigations: current utility, limitations, and ongoing developments. Research and Reports in Forensic Medical Science, 6, 25. DOI: $10.2147 /$ RRFMS.S93974

Grieshaber, B. M., Osborne, D. L., Doubleday, A. F., ve Kaestle, F. A. (2008). A pilot study into the effects of X-ray and computed tomography exposure on the amplification of DNA from bone. Journal of Archaeological Science, 35, 681-687. DOI: $10.1016 /$ j.jas.2007.06.001

Haglund, W. D., ve Sorg, M. H. (2010). Advances in forensic taphonomy: method, theory, and archaeological perspectives. Boca Raton: CRC 
Press. DOI: $10.1201 / 9781420058352$

Høyer, C. B., Nielsen, T. S., Nagel, L. L., Uhrenholt, L., ve Boel, L.

W. T. (2012). Investigation of a fatal airplane crash: autopsy, computed tomography, and injury pattern analysis used to determine who was steering the plane at the time of the accident. A case report. Forensic Science, Medicine, and Pathology, 8(2), 179-188. DOI: $10.1007 /$ s12024-011-9239-4

Iino, M., ve Aoki, Y. (2016). The use of radiology in the Japanese tsunami DVI process. Journal of Forensic Radiology and Imaging, 4, 20-26. DOI: $10.1016 /$ i.jofri.2015.12.006

Kahana, T., ve Hiss, J. (1997). Identification of human remains: forensic radiology. Journal of Clinical Forensic Medicine, 4(1), 7-15. DOI: 10.1016/S1353-1131(97)90002-X

Kahana, T., ve Hiss, J. (1999). Forensic radiology. The British Journal of Radiology, 72(854), 129-133. DOI: 10.1259/ bir.72.854.10365061

Katzenberg, M., ve Saunders, S. (2011). Biological Anthropology of the Human Skeleton (Second Edition). New Jersey: John Wiley \& Sons, Inc. DOI: 10.1002/9780470245842

Kuhn, G., Schultz, M., Müller, R., ve Rühli, F. J. (2007). Diagnostic value of micro-CT in comparison with histology in the qualitative assessment of historical human postcranial bone pathologies. HOMO, 58(2), 97-115. DOI: 10.1016/j. jchb.2006.11.002

Kullmer, O. (2008). Benefits and risks in virtual anthropology. Journal of Anthropological Sciences, 86, 205-207.

Le Blanc-Louvry, I., Thureau, S., Duval, C., Papin-Lefebvre, F., Thiebot, J., Dacher, J. N., ve Proust, B. (2013). Post-mortem computed tomography compared to forensic autopsy findings: a French experience. European Radiology, 23(7), 1829_ 1835. DOI: $10.1007 /$ s00330-013-2779-0

Le Cabec, A., Tang, N., ve Tafforeau, P. (2015). Accessing Developmental Information of Fossil Hominin Teeth Using New Synchrotron Microtomography-Based Visualization Techniques of Dental Surfaces and Interfaces. PLOS ONE, 10(4), e0123019. DOI: $10.1371 /$ journal.pone.0123019

Manifold, B. M. (2014). Bone Mineral Density in Children From Anthropological and Clinical Sciences: A Review. Anthropological Review, 77(2), 111-135. DOI: 10.2478/anre2014-0011

Márquez-Grant, N. (2015). An overview of age estimation in forensic anthropology: perspectives and practical considerations. Annals of Human Biology, 42(4), 308-322. DOI: $10.3109 / 03014460.2015 .1048288$

Mays, S. (2007). Radiography and Allied Techniques in the Palaeopathology of Skeletal Remains. In R. Pinhasi \& S. Mays (Eds.), Advances in Human Palaeopathology (pp. 77-100). Chichester, UK: John Wiley \& Sons, Ltd. DOI: 10.1002/9780470724187.ch5

Mazurier, A., Volpato, V., ve Macchiarelli, R. (2006). Improved noninvasive microstructural analysis of fossil tissues by means of SR-microtomography. Applied Physics A, 83(2), 229-233. DOI: $10.1007 / \mathrm{s} 00339-006-3511-6$

McCormick, W. F. (1980). Mineralization of the costal cartilages as an indicator of age: preliminary observations. Journal of Forensic Sciences, 25(4), 736-741.

Middleham, H. P., Boyd, L. E., ve Mcdonald, S. W. (2015). Sex determination from calcification of costal cartilages in a Scottish sample. Clinical Anatomy, 28(7), 888-895. DOI: $10.1002 / \mathrm{ca} .22491$

O’Donnell, C., Iino, M., Mansharan, K., Leditscke, J., ve Woodford, N. (2011). Contribution of postmortem multidetector CT scanning to identification of the deceased in a mass disaster: experience gained from the 2009 Victorian bushfires. Forensic Science International, 205(1-3), 15-28. DOI: 10.1016/j. forsciint.2010.05.026

Rein, T. R., ve Harvati, K. (2014). Geometric Morphometrics and Virtual Anthropology: Advances in human evolutionary studies. Anthropologischer Anzeiger, 71(1), 41-55. DOI: 10.1127/0003-5548/2014/0385

Riepert, T., Rittner, C., Ulmcke, D., Ogbuihi, S., ve Schweden, F. (1995). Identification of an unknown corpse by means of computed tomography (CT) of the lumbar spine. Journal of Forensic Sciences, 40(1), 126-127.

Ritman, E. L. (2011). Current Status of Developments and Applications of Micro-CT. Annual Review of Biomedical Engineering, 13(1), 531-552. DOI: 10.1146/annurevbioeng-071910-124717

Robb, R. A. (1985). Three-dimensional biomedical imaging. Boca Raton: CRC Press Inc.

Rock, C., Viner, M., ve Hines, E. (2006). Radiography. In T. Thompson \& S. Black (Eds.), Forensic Human Identification: An Introduction (pp. 221-228). CRC Press. DOI: 10.1201/9781420005714.ch12

Rougé, D., Telmon, N., Arrue, P., ve Larrouy, G., ve Arbus, L. (1993). Radiographic identification of human remains through deformities and anomalies of post-cranial bones: a report of two cases. Journal of Forensic Sciences, 38(4), 997-1007.

Ruder, T. D., Kraehenbuehl, M., Gotsmy, W. F., Mathier, S., Ebert, L. C., Thali, M. J., ve Hatch, G. M. (2012). Radiologic identification of disaster victims: a simple and reliable method using CT of the paranasal sinuses. European Journal of Radiology, 81(2), e132-e138. DOI: 10.1016/j.ejrad.2011.01.060

Rutty, G., Brough, A., Biggs, M. J., Robinson, C., Lawes, S. D., ve Hainsworth, S. (2013). The role of microcomputed tomography in forensic investigations. Forensic Science International, 225(1-3), 60-66. DOI: 10.1016/J. FORSCIINT.2012.10.030

Rutty, G ., Robinson, C. E., BouHaidar, R., Jeffery, A. J., ve Morgan, B. (2007). The role of mobile computed tomography in mass fatality incidents. Journal of Forensic Sciences, 52(6), 1343-1349. DOI: $10.1111 / \mathrm{j} .1556-4029.2007 .00548 . \mathrm{x}$

Saint-Martin, P., Rérolle, C., Dedouit, F., Bouilleau, L., Rousseau, H., Rougé, D., ve Telmon, N. (2013). Age estimation by magnetic resonance imaging of the distal tibial epiphysis and the calcaneum. International Journal of Legal Medicine, 127(5), 1023-1030. DOI: $10.1007 / \mathrm{s} 00414-013-0844-5$

Salzer, R. (Ed.) (2012). Biomedical Imaging: Principles and 
applications. Hoboken, NJ: John Wiley \& Sons, Inc. DOI: $\underline{10.1002 / 9781118271933}$

Serin, J., Rérolle, C., Pucheux, J., Dedouit, F., Telmon, N., Savall, F., ve Saint-Martin, P. (2016). Contribution of magnetic resonance imaging of the wrist and hand to forensic age assessment. International Journal of Legal Medicine, 130(4), 11211128. DOI: $10.1007 / \mathrm{s} 00414-016-1362-\mathrm{Z}$

Spoor, F., Jeffery, N., ve Zonneveld, F. (2000). Using diagnostic radiology in human evolutionary studies. Journal of Anatomy, 197(1), 61-76. DOI: $10.1046 / j .1469-7580.2000 .19710061 . x$

Steinberger, J., Jacobs, D. R., Raatz, S., Moran, A., Hong, C.P., ve Sinaiko, A. R. (2005). Comparison of body fatness measurements by BMI and skinfolds vs dual energy X-ray absorptiometry and their relation to cardiovascular risk factors in adolescents. International Journal of Obesity, 29(11), 1346-1352. DOI: $10.1038 /$ si.ijo.0803026

Stull, K. E., Tise, M. L., Ali, Z., ve Fowler, D. R. (2014). Accuracy and reliability of measurements obtained from computed tomography 3D volume rendered images. Forensic Science International, 238, 133-140. DOI: 10.1016/i. forsciint.2014.03.005

Thali, M. J., Taubenreuther, U., Karolczak, M., Braun, M., Brueschweiler, W., Kalender, W. A., ve Dirnhofer, R. (2003). Forensic microradiology: micro-computed tomography (Micro-CT) and analysis of patterned injuries inside of bone. Journal of Forensic Sciences, 48(6), 1336-1342.

Thali, M. J., Viner, M. D., ve Brogdon, B. G. (2011). Brogdon's Forensic Radiology (Second Edition). Boca Raton: CRC Press.

Uldin, T. (2017). Virtualanthropology-abrief review of theliterature and history of computed tomography. Forensic Sciences Research, 2(4), 165-173. DOI: $10.1080 / 20961790.2017 .1369621$

Villa, C., Buckberry, J., ve Lynnerup, N. (2016). Evaluating osteological ageing from digital data. Journal of Anatomy, 235(2), 386-395. DOI: $10.1111 /$ joa.12544

Viner, M. (2018). Chapter 19 - Overview of Advances in Forensic Radiological Methods of Human Identification. New Perspectives in Forensic Human Skeletal Identification, 217-226. DOI: $10.1016 /$ B978-0-12-805429-1.00019-3

Wade, A. D., Holdsworth, D. W., ve Garvin, G. J. (2011). CT and micro-CT analysis of a case of Paget's disease (osteitis deformans) in the Grant skeletal collection. International Journal of Osteoarchaeology, 21(2), 127-135. DOI: 10.1002/oa.1111

Weber, G. W., Schäfer, K., Prossinger, H., Gunz, P., Mitteröcker, P. ve Seidler, H. (2001). Virtual Anthropology: The Digital Evolution in Anthropological Sciences. Journal of PHYSIOLOGICAL ANTHROPOLOGY and Applied Human Science, 20(2), 69-80. DOI: 10.2114/jpa.20.69

Wheatley, B. P. (2005). An evaluation of sex and body weight determination from the proximal femur using DXA technology and its potential for forensic anthropology. Forensic Science International, 147(2-3), 141-145. DOI: 10.1016/j.forsciint.2004.09.076

Wu, X., ve Schepartz, L. A. (2009). Application of computed tomography in paleoanthropological research. Progress in Natural Science, 19(8), 913-921. DOI: 10.1016/i. pnsc.2008.10.009 